\title{
Profile of female deaths by homicide in the city of Goiânia
}

\author{
Perfil dos óbitos femininos por homicídios no município de Goiânia \\ Perfil de homicidio muerte de mujeres en la ciudad de Goiania
}

\section{Luana Muzzi Vaz David' \\ ORCID: 0000-0003-2987-1515 \\ Ruth Minamisava" \\ ORCID: 0000-0001-9352-5567}

Priscila Valverde de Oliveira Vitorino ORCID: 0000-0002-5487-4649

Maria José Pereira Rocha ORCID: 0000-0002-4310-1579

Viviane Santos Mendes Carneiro' ORCID: 0000-0001-7497-5888

Maria Aparecida da Silva Vieira' ORCID: 0000-0001-8101-1729

'Pontifícia Universidade Católica de Goiás. Goiânia, Goiás, Brazil. "Universidade Federal de Goiás. Goiânia, Goiás, Brazil.

How to cite this article: David LMV, Minamisava R, Vitorino PVO, Rocha MJP, Carneiro VSM, Vieira MAS. Profile of female deaths by homicide in the city of Goiânia. Rev Bras Enferm. 2020;73(Suppl 4):e20180985. doi: http://dx.doi.org/10.1590/0034-7167-2018-0985

\section{Corresponding author:}

Maria Aparecida da Silva Vieira

E-mail: cidavi00@gmail.com

EDITOR IN CHIEF: Antonio José de Almeida Filho ASSOCIATE EDITOR: Cristina Parada

Submission: 02-20-2019

Approval: 03-09-2020

\section{ABSTRACT}

Objectives: to identify the female homicide profile in the city of Goiânia. Methods: a crosssectional, descriptive study that characterized female deaths by homicide from 2008 to 2015. They occurred in Goiânia, and registered in the Mortality Information System. Cases of homicide of women aged $\geq 10$ years were eligible. Other causes of death were excluded. Descriptive statistical analysis with frequencies. Results: three hundred seventy-six women died from assault, with an increase in the percentage of deaths annually. Most of the victims were young $(57.5 \%)$, single (78.8\%), mixed-ethnicity $(61.1 \%)$ and with low education (58.4\%). The most frequent means of assault was firearm (64.0\%). The health districts with the highest record of female deaths due to assault were southwest, center and northwest. Conclusions: the predominant profile of women victims of femicide was young, mixed-ethnicity, single, with low level of education and living in less favored regions.

Descriptors: Gender-Based Violence; Violence Against Women; Homicide; Violence; Battered Women

\section{RESUMO}

Objetivos: identificar o perfil de homicídios femininos no município de Goiânia, Goiás. Métodos: estudo transversal, descritivo, que caracterizou os óbitos femininos por homicídios de 2008 a 2015, ocorridos em Goiânia, registrados no Sistema de Informação sobre Mortalidade. Foram elegíveis casos de homicídios de mulheres com idade $\geq 10$ anos que residiam em Goiânia. Foram excluídas as outras causas de morte. Análise estatística descritiva com frequências. Resultados: 376 mulheres morreram por agressão, observando-se um aumento da porcentagem de óbitos anualmente. A maioria das vítimas era jovens $(57,5 \%)$, solteiras $(78,8 \%)$, pardas $(61,1 \%)$ e de baixa escolaridade (58,4\%). O meio de agressão mais frequente foi com arma de fogo $(64,0 \%)$. Os distritos sanitários com maior registro de óbitos femininos por agressão foram Sudoeste, Centro e Noroeste, respectivamente. Conclusões: o perfil predominante das mulheres vítimas de feminicídio foi jovens, pardas, solteiras, com baixo nível de escolaridade e moradoras de regiões menos favorecidas.

Descritores: Violência de Gênero, Violência contra a Mulher, Homicídio, Violência, Mulheres Maltratadas.

\section{RESUMEN}

Objetivos: identificar el perfil de homicidios femeninos en la cuidad de Goiânia. Métodos: estudio descriptivo transversal que caracterizó las muertes de mujeres por homicidios de 2008 a 2015, ocurridas en Goiânia, registradas en el Sistema de Información de Mortalidad. Los casos de homicidio de mujeres $\geq 10$ años que vivían en Goiânia eran elegibles. Se excluyeron otras causas de muerte. Análisis estadístico descriptivo con frecuencias. Resultados: 376 mujeres murieron por agresión, con un aumento en el porcentaje de muertes anuales. La mayoría de las víctimas eran jóvenes (57.5\%), solteras ( $78.8 \%)$, mestizas (61.1\%) y con baja educación (58.4\%). El medio de agresión más frecuente fue con un arma de fuego (64.0\%). Los distritos de salud con el mayor número de muertes de mujeres debido a la agresión fueron Suroeste, Centro y Noroeste, respectivamente. Conclusiones: el perfil predominante de mujeres víctimas de feminicidio era joven, morena, soltera, con bajo nivel educativo y viviendo en regiones menos favorecidas.

Descriptores: Violencia de Género; Violencia contra la Mujer; Homicidio;Violencia; Mujeres Maltratadas. 


\section{INTRODUCTION}

Violence against women is considered an important public health problem, due to the high prevalence of cases identified in several countries, especially those committed by intimate partners ${ }^{(1)}$.

In North America, it is estimated that between $60 \%$ and $70 \%$ of female homicide in the United States and Canada are committed by intimate partners ${ }^{(1-2)}$. Other investigators suggest that the greatest risk of female homicide is by partners or ex-partners ${ }^{(3)}$. Similarly, in the United Kingdom, in 2009, 54\% of female deaths and $5 \%$ of male deaths were committed by intimate partners ${ }^{(4)}$. Another retrospective study carried out in 1999 and 2009 in South Africa found that about $50 \%$ of female homicide were committed by spouses ${ }^{(5)}$.

Female deaths for which gender-based discrimination was the only reason they were named femicides in 1976 by Diana Russel ${ }^{(6)}$. Women deaths caused by gender conflicts represent the maximum expression of violence. Intimate partner physical violence against women was the main risk factor for femicide. These deaths result from situations of abuse at home, threats, sexual violence, and situations in which women have less power and resources than men $^{(2-3)}$.

With regard to female homicide, Brazil ranks fifth among 84 countries in the world $^{(7)}$. From 2009 to 2011, 13,071 femicides were registered in the Brazilian Mortality Information System (Sistema de Informação de Mortalidade, abbreviated SIM, corresponding to U.S.' National Vital Statistics System), which is equivalent to a crude mortality rate of 4.48 deaths per 100,000 women $^{(8)}$. Among the Brazilian states, the State of Goiás ranks sixth place, since 6.9 cases of femicide were registered per 100 thousand women ${ }^{(8)}$.

In the last decades, several international and national public policies were created with the purpose of giving a different treatment to gender issues, including femicide. Among public policies, the creation of UN Women by the United Nations in 2010 stands out. This entity plays a global leadership role in the defense of women around the world. It seeks to expand global efforts to defend women's human rights, placing gender equality as an important condition for achieving development ${ }^{(9)}$. In Brazil, Law 11.340 - known as Maria da Penha Law - came into force in 2006, which defines domestic and family violence against women as a crime, allowing offenders of women to be caught in the act or to have their preventive detention decreed ${ }^{(10)}$. However, a time series study, conducted to assess the impact of the Maria da Penha Law on the mortality of women due to assault, found that there was no impact, that is, there was no reduction in the annual mortality rates ${ }^{(11)}$.

In a new attempt to reduce violence against women, the Brazilian government, in 2015, approved the bill to classify femicide as a heinous crime and qualify the murder of women due to gender reasons. Thus, murder motivated by gender becomes a homicide qualified with imprisonment for 12 to 30 years ${ }^{(12)}$.

Although gender violence is an important social and human rights problem, there is still little information about the magnitude of this phenomenon. A search was conducted using the PICO strategy (P: female/women; I: homicide/femicide; CO: Brazilian) in five databases (Virtual Health Library, PubMed, LILACS, BIREME and Scielo) identified 35 articles. Of these, four studied femicide in Brazil(13-16) and only one evaluated the city of Goiânia in order to analyze the relationship between femicides and various indicators ${ }^{(16)}$. In this setting, this is the first study that proposes to contribute to the visibility of this event by obtaining population data on the profile and distribution of female deaths from homicide in Goiânia's health districts.

\section{OBJECTIVES}

To identify the female homicide profile in the city of Goiânia, State of Goiás.

\section{METHODS}

\section{Ethical aspects}

Although it used secondary data available for public consultation, the study was approved by the Ethics Committee of the Universidade Pontifícia Católica de Goiás - PUC Goiás (Opinion $1,616,347)$ on June 30, 2016. All ethical guidelines established by CNS (Conselho Nacional de Saúde - Brazilian National Health Board) Resolution 466, of December 12, 2012, which regulates research involving human beings, were followed.

\section{Study design, period and location}

This is a cross-sectional and descriptive study, guided by the STROBE tool, which analyzed the epidemiological profile of cases of deaths of women by homicide in Goiânia, based in the central region of Brazil between 2008 and 2015. The city is divided into seven health districts (North, South, East, West, Northwest, Southwest and Campinas-Center). The secondary database used to obtain the data was the SIM.

\section{Population, inclusion and exclusion criteria}

The study population was all women aged ten years or older, living in the city of Goiânia, who died during the study period.

The study inclusion criteria were homicide of women aged ten years and older who lived in Goiânia. All other causes of death in the city of Goiânia were excluded.

\section{Study protocol}

Death distribution was performed based on the variable of the victims' place of residence, designated in the SIM databse as CODBAIRRORES (public domain variable).

The femicide category is not included in the SIM. Also, similar to other studies, the total number of female homicide was used as an "approximate indicator" of femicide, since $60 \%$ to $70 \%$ of these deaths are caused by gender inequalities ${ }^{(2,14)}$. The use of total deaths as an approximation of cases of femicide does not overestimate the mortality from this event, in view of the compensation for underreporting or ill-defined diagnoses of assault in women, especially in the poorest regions of the country ${ }^{(17)}$.

Female homicide was considered according to the categories of the $10^{\text {th }}$ edition of the International Classification of Diseases (ICD-10), from X85 to Y09. This classification covers homicide and injuries inflicted by another person, using any means with intention of injuring or killing, as shown in Chart 1. 
Chart 1 - Categories of the $10^{\text {th }}$ edition of the International Classification of Diseases (ICD-10), from X85 to Y09

\begin{tabular}{|l|c|}
\hline Cause of Death & ICD code 10 \\
\hline $\begin{array}{l}\text { Assault by drugs, medicaments and biological } \\
\text { substances; by corrosive substance; by pesticides }\end{array}$ & $\mathrm{X} 85 ; \mathrm{X} 86 ; \mathrm{X} 87$ \\
\hline Assault by gases and vapours & $\mathrm{X} 88$ \\
\hline $\begin{array}{l}\text { Assault by other specified and unspecified chemicals } \\
\text { and noxious substances }\end{array}$ & $\mathrm{X} 89 ; \mathrm{X} 90$ \\
\hline Assault by hanging, strangulation and suffocation & $\mathrm{X} 91$ \\
\hline Assault by drowning and submersion & $\mathrm{X} 92$ \\
\hline Assault by firearm & $\mathrm{X} 93 ; \mathrm{X} 94 ; \mathrm{X} 95$ \\
\hline Assault by explosive material & $\mathrm{X} 96$ \\
\hline Assault by smoke, fire and flames & $\mathrm{X} 97$ \\
\hline Assault by steam, hot vapors and hot objects & $\mathrm{X} 98$ \\
\hline Assault by sharp object & $\mathrm{X} 99$ \\
\hline Assault by blunt object & $\mathrm{Y} 00$ \\
\hline Assault by pushing from high place & $\mathrm{Y} 01$ \\
\hline $\begin{array}{l}\text { Assault by pushing or placing victim in front of a } \\
\text { moving object }\end{array}$ & $\mathrm{Y} 02$ \\
\hline Assault by crashing of motor vehicle & $\mathrm{Y} 03$ \\
\hline Assault by bodily force and by physical strength & \\
\hline
\end{tabular}

The variables were classified into: (i) sociodemographic characteristics - age group (in years); race (white, black, yellow, mixedethnicity); marital status (married, single, widow, separated); education (in years); (ii) characteristics of the occurrence of death - year of death (from 2008 to 2015); weekdays (Monday, Tuesday, Wednesday, Thursday, Friday, Saturday and Sunday); month of occurrence (January to December); means of assault (firearm, sharp object, hanging, suffocation or strangulation, fire, smoke and flames); place of death (hospital, public roads, home, others); neighborhood where the victims lived, grouped by health districts.

\section{Analysis of results and statistics}

A database was built using the Statistical Package for the Social Science (SPSS), version 20, on Windows platform. Typing was performed by researchers with experience in handling the DATASUS system, with the support of a statistician. A descriptive analysis was carried out to characterize the profile of the victims through tables of distribution of absolute and relative frequencies of the variables for all cases of deaths of women by homicide, declared by SIM.

\section{RESULTS}

In Goiânia, 376 women died from assault between 2008 and 2015. Table 1 presents sociodemographic characteristics and occurrences of female homicide in this period.
Most of the victims were women aged 20 to 39 years $(57.5 \%)$, single (78.8\%), mixed-ethnicity (61.1\%) and had low education (58.4\%). Approximately $20 \%$ of female deaths occurred among adolescents.

Regarding the means of assault suffered by the victims, firearm use $(64.0 \%)$ stands out, followed by sharp object (25.3\%). The most frequent place of death was public roads (36.2\%), followed by hospitals (24.5\%) and home (23.9\%) (Table 1 ).

Table 1 - Sociodemographic and occurrence characteristics of women victims of homicide living in the city of Goiânia, Goiás, Brazil, 2008-2015

\begin{tabular}{|c|c|c|}
\hline Variables & $\mathbf{n}$ & $\%$ \\
\hline \multicolumn{3}{|l|}{ Sociodemographic characteristics } \\
\hline \multicolumn{3}{|l|}{ Age group (years)* } \\
\hline $10-19$ & 74 & 19.9 \\
\hline $20-39$ & 214 & 57.5 \\
\hline $40-59$ & 67 & 18.0 \\
\hline$\geq 60$ & 17 & 4.6 \\
\hline \multicolumn{3}{|l|}{ Race $^{*}$} \\
\hline Mixed-ethnicity & 222 & 61.1 \\
\hline White & 124 & 34.2 \\
\hline Black & 17 & 4.7 \\
\hline \multicolumn{3}{|l|}{ Marital Status* } \\
\hline Single & 82 & 78.8 \\
\hline Separated & 11 & 10.6 \\
\hline Married & 9 & 8.7 \\
\hline Widow & 2 & 1.9 \\
\hline \multicolumn{3}{|l|}{ Education (years)* } \\
\hline$<8$ & 143 & 58.4 \\
\hline $8-11$ & 78 & 31.8 \\
\hline$\geq 12$ & 24 & 9.8 \\
\hline \multicolumn{3}{|l|}{ Characteristics of occurrence } \\
\hline \multicolumn{3}{|l|}{ Means of assault** } \\
\hline Firearm & 241 & 64.0 \\
\hline Sharp object & 95 & 25.3 \\
\hline Hanging, suffocation and strangulation & 22 & 5.9 \\
\hline Fire, smoke and flames & 6 & 1.6 \\
\hline Bodily force & 6 & 1.6 \\
\hline Blunt object & 6 & 1.6 \\
\hline \multicolumn{3}{|l|}{ Place of death } \\
\hline Public roads & 136 & 36.2 \\
\hline Hospital & 92 & 24.5 \\
\hline Home & 90 & 23.9 \\
\hline Other & 58 & 15.4 \\
\hline
\end{tabular}

Source: Mortality Information System (SIM/DATASUS).

Note: *The total number is not the same for all variables because blank values have been excluded from the analysis; **International Classification of Diseases (ICD-10).

As for the year in which femicide occurred, there was an increase in its proportion during the study period: $8.2 \%$ in 2008 , reaching $20.7 \%$ in 2014, and a slight drop in 2015, as shown in Figure 1.

The health districts where most female deaths from assault occurred were the Southwest (19.5\%), followed by Campinas-Center (17.3\%), Northwest (16.7\%), East (13.5\%), South (11.4\%), West (11.1\%) and North (10.5\%). Among the records of female deaths due to assault, $9.3 \%$ had no records of the region where the victims lived.

The distribution of deaths that occurred during the study period, according to weekdays, shows that 141 deaths occurred during the weekends (37.5\%). The percentage of the number of deaths was $18.9 \%$ on Sundays, $18.6 \%$ on Saturdays and $8.5 \%$ on Mondays (Figure 2).

Figure 3 lists the distribution of femicides, according to the month of the year. The highest percentages correspond to April, September, October and January, respectively. 


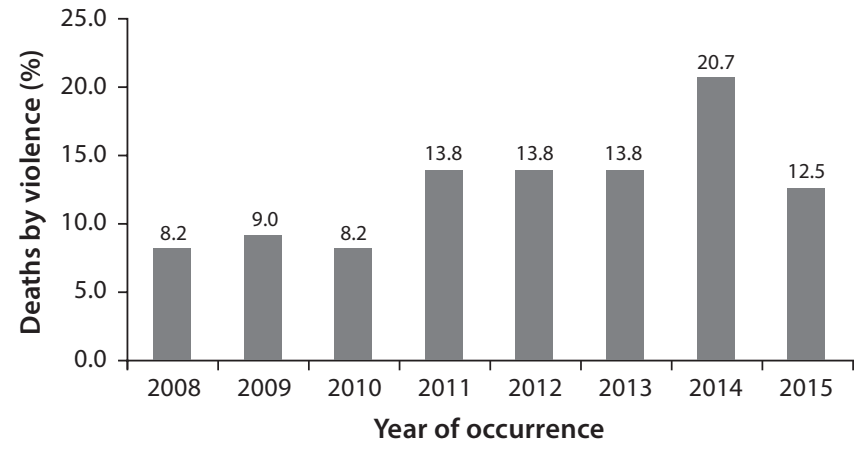

Source: Mortality Information System (SIM/DATASUS).

Figure 1 - Percentage of deaths due to violence against women according to the year of occurrence, Goiânia, Goiás, Brazil, 2008-2015

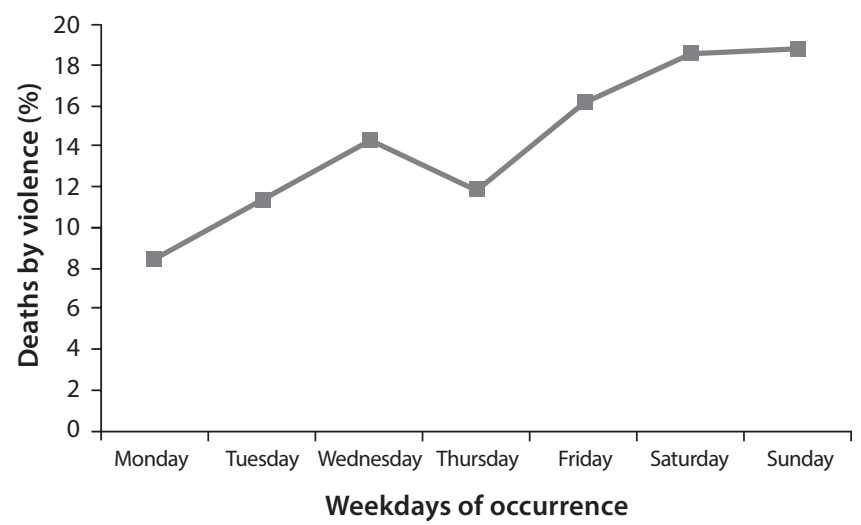

Source: Mortality Information System (SIM/DATASUS).

Figure 2 - Percentage of deaths due to violence against women according to the weekdays of occurrence, in victims from Goiânia, Goiás, Brazil, 2008-2015

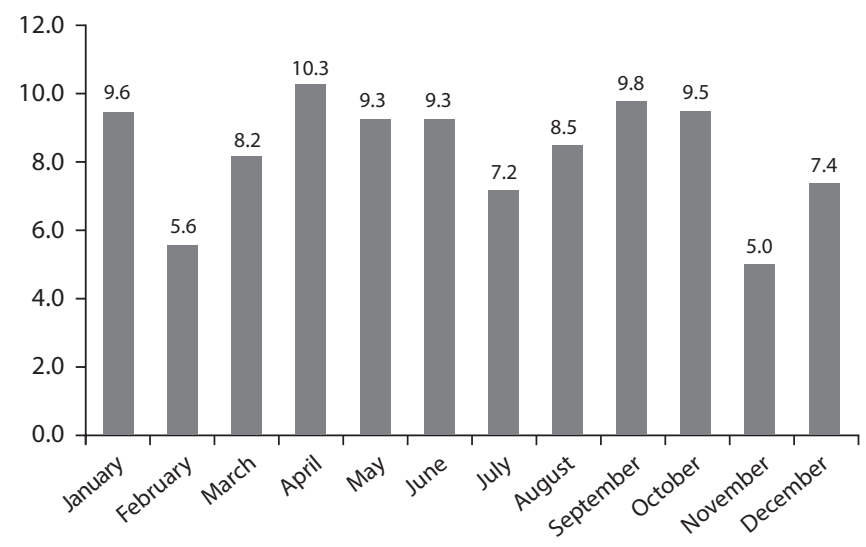

Source: Mortality Information System (SIM).

Figure 3 - Percentage of deaths due to violence against women according to the months of the year of occurrence, in victims from Goiânia, Goiás, Brazil, 2008-2015

\section{DISCUSSION}

The predominant profile of deaths observed was that of young, single, mixed-ethnicity, poorly educated victims and residents in less favored regions of the city. Other studies, international and national, have also identified the relationship between violence against women with these characteristics, also associating this type of violence with black and unemployed women ${ }^{(11,18-22)}$.
Similar to our findings, in the United States, relationships were found between rates of femicide and places of greatest poverty, instability, black population, unemployment and violent crime rates ${ }^{(2)}$. In Latin America, many murdered women are prostitutes, young people, with low purchasing power, from slum areas, who perform precarious jobs and are in a situation of high vulnerability ${ }^{(23)}$.

On the other hand; this study identified that $10 \%$ of deaths occurred among women with higher education, contradicting the literature ${ }^{(11,14)}$. This might happen due to change in traditional gender roles. Women entry into the formal workforce allows many to achieve their economic independence, which is potentially a source of conflict. Men, when lose the role of provider and head of the family, often react aggressively, and this can increase the number of situations of violence among genders, including femicides ${ }^{(19)}$.

Although the literature brings conflicting results in relation to the victim's marital status, an American study, similar to our findings, found that single women had a higher risk of homicide than married women ${ }^{(2)}$. In Brazil, other researchers have also shown a higher risk of femicides among single women ${ }^{(14)}$. For married women, the period in which they are trying to achieve separation represents a risk situation for femicide ${ }^{(24)}$. However, it is not clear whether this danger is greater than staying in an abusive relationship. Therefore, is important that other studies are carried out to assess whether there is an association between marital status and femicide.

In this study, there was an increase in the proportion of homicide among women between 2008 (8.2\%) and 2015 (12.5\%). A study conducted with data from all over Brazil also identified an increase in the prevalence of femicide over the years. In other countries, the reality is no different, especially in homicide caused by an intimate partner. Intimate partner violence prevalence is variable $^{(11)}$, ranging from $13 \%$ to $71 \%$. A systematic review with data obtained from 66 countries showed that overall, $13.5 \%$ of homicide were committed by an intimate partner, and this proportion was six times higher for female homicide than for male homicide. Percentages of homicide by intimate partners were higher in high-income countries and Southeast Asia(3). However, high rates of femicide have also been found in developing countries, especially in Latin America and the Caribbean ${ }^{(25)}$. These results highlight the need for effective public policies to reduce female homicide rates.

In Goiânia, in 2014, there was a greater number of female homicide. This happens because of the figure of a serial killer that promoted an abrupt increase in female deaths in the city (20.7\%), in this period. The serial killer was arrested in October 2014, when he confessed to murdering 39 people, mostly women, between 2011 and 2014. Of the women, two would be call girls. Among the men, some would be homeless and homosexuals. As of the end of 2013, he started to kill only women, mostly young men, chosen at random while he was riding $a^{(26)}$ motorcycle. The catastrophes could be prevented with active epidemiological surveillance to monitor the female homicide rate and act in a timely manner to prevent outbreaks like this.

Three regions stood out in relation to the frequency of female homicide in the city of Goiânia (Northeast, Southeast and Center), corresponding to more than half of femicides (53.5\%), distributed 
in the seven health districts. This disparity in the distribution of female deaths identified emphasizes the great intra-urban spatial inequality, evidencing high concentrations of deaths in less favored regions of the city.

The literature also shows that economically disadvantaged regions have a higher homicide rate related to the gender ${ }^{(5,11,27)}$. In Brazil, a study designed to verify the main causes of death, identified an increase in the rates of femicide in the regions with the worst socioeconomic indicators ${ }^{(28)}$. Such regions are linked to areas of greater violence with a large number of male homicide, which increases homicide by gender, since aggressive and sexist behaviors prevail in these environments ${ }^{(27)}$. Therefore, where society is more violent, women are more penalized ${ }^{(19,27,29)}$.

Regarding the Center of Goiânia, despite being an economically more favored region, it is also marked by social destabilization, since it is a region characterized by places of prostitution. A study conducted in Goiânia, to characterize the profile of female sex workers, using the Respondent-Driven Sampling (RDS), a sampling methodology, identified the central region of Goiânia as one of the places of women prostitution. Goiânia is also considered an important route for prostitution and national and international sexual tourism ${ }^{(30)}$. Other investigators have shown femicides in stigmatized populations, whose victims belong to marginalized populations such as homeless people and sex workers ${ }^{(31)}$. On the other hand, there is a discourse that minimizes crimes when murdered women are addicted to drugs or prostitutes leading to the naturalization of violence. A study that looked at the behavior of men who pay to have sex, conducted in the United States, found that sex buyers were more likely to report sexual assault and rape ${ }^{(32)}$. For this population, geographical space appears as a potential threat for cases of femicide.

Regarding the type of occurrence, firearm was the most used means of assault (64.0\%) in this research. Most deaths are committed by an intimate partner and involve firearms ${ }^{(33)}$. Therefore, a weapon that may have been purchased for family defense can become a threat where there are cases of domestic violence.

The results of the present study identified that the majority of female homicide occurred on weekends and during vacation months. This finding is consistent with a Brazilian study, in which more than a third of female deaths occurred during weekends $s^{(11)}$. A possible explanation for this is that this may be the period in which abusers spend more time with women, since in most cases, they are not working. Another factor may refer to the higher consumption of alcoholic beverages in this period of the week, which leads to an increase in domestic violence ${ }^{(34)}$.

Public roads stood out as the most frequent place of death in the present study. However, most studies that correlate female homicide with the gender issue have a higher prevalence of home deaths ${ }^{(19)}$. However, no significant discrepancy was found in the literature between the variables public roads, home, and hospitals ${ }^{(11)}$.

\section{Study limitations}

One of the limitations of this study is the use of secondary data for the study of homicide against women, since there may be problems in the diagnosis and in filling out death certificates, since many homicide are considered accidents or suicides ${ }^{(7)}$. Another limitation was the identification of ignored values or blank data in the database ("missing data") in some variables, with emphasis on victims' marital situation and education, impairing the knowledge of their characteristics.

\section{Contributions to public policies}

This study may contribute to expanding surveillance activities on registration quality of women deaths, thus allowing greater visibility in Brazil. It also helps to understand the profile of women who have suffered violence and died as a result of this fact, in order to know which population of women is most vulnerable to this fatality.

\section{CONCLUSIONS}

This study identified the profile of violent deaths of women in the city of Goiânia, distributed by health districts, based on the SIM database. The investigated population was formed predominantly by young, mixed-ethnicity, single women, with low level of education and living in peripheral regions. The highest percentages of femicides occurred on weekends and on vacation months. It is worth mentioning that it is still necessary to broad the understanding of gender violence in the city through new studies that obtain qualitative information to understand this complex reality in which ethnicity, social class and gender interact.

\section{REFERENCES}

1. World Health Organization. Global and regional estimates of violence against women: prevalence and health effects of intimate partner violence and non-partner sexual violence[Internet]. World Health Organization; 2013[cited 2018 Jun 13]. Available from: https://apps.who. int/iris/bitstream/handle/10665/85239/9789241564625_eng.pdf;jsessionid=C2B1BC6807B33F0E72F3125851BBF935?sequence=1

2. Campbell JC, Glass N, Sharps PW, Laughon K, Bloom T. Intimate partner homicide: review and implications of research and policy. Trauma Violence Abuse. 2007;8(3):246-69. doi: 10.1177/1524838007303505.

3. Stöckl H, Devries K, Rotstein A. The global prevalence of intimate partner homicide: a systematic review. Lancet. 2013;382(9895):859-65. doi: 10.1016/S0140-6736(13)61030-2

4. Smith K, Coleman K, Eder S, Hall P. Homicides, firearm offences and intimate violence 2009/10 (Crime in England and Wales). Home Office Statistical Bulletin[Internet]. 2011 [cited 2018 Jun 13]:118 Available from: https://assets.publishing.service.gov.uk/government/uploads/ system/uploads/attachment_data/file/116483/hosb0212.pdf 
5. Abrahams N, Mathews S, Martin LJ, Lombard C, Jewkes R. Intimate partner femicide in South Africa in 1999 and 2009. PLoS Med [Internet]. 2013 [cited 2017 Aug 28];10(4):132-8 Available from: https://journals.plos.org/plosmedicine/article?id=10.1371/journal.pmed.1001412

6. Russel DEH, Harmes R. Defining Feminicide and related concepts. In: Russel DEH, Harmes R, (eds.). Feminicide in global perspective. New York: Teacher's College Press, 2001, 12-8 p.

7. Waiselfisz JJ. Mapa da Violência 2015: homicídios de mulheres no Brasil[Internet]. 2015[cited 2017 Aug 28]. 79 p. Available from: https:// www.mapadaviolencia.org.br/pdf2015/MapaViolencia_2015_mulheres.pdf.

8. Garcia LP, Freitas LRS, Silva GDM, Höfelmann DA. Estimativas corrigidas de feminicídios no Brasil, 2009 a 2011. Rev Panam Salud Publica [Internet]. 2015[cited 2017 Aug 28];37:251-7 Available from: https://www.scielosp.org/pdf/rpsp/2015.v37n4-5/251-257/pt

9. Organização das Nações Unidas. ONU Mulheres Brasil[Internet]. 2010[cited 2017 Aug 28]. Available from: http://www.onumulheres.org.br/ onu-mulheres/sobre-a-onu-mulheres/

10. Presidência da República (BR). Lei n. 11.340 de 7 de agosto de 2006. Lei Maria da Penha. Dispõe sobre a criação dos Juizados de Violência Doméstica e Familiar contra a mulher, altera o Código de Processo Penal, o Códio Penal e a Lei de Execução Pena e dá outras providências [Internet]. Brasília: Diário Oficial da União, 2006[cited 2017 Aug 28]. Available from: http://www.planalto.gov.br/ccivil_03/_ato20042006/2006/lei/l11340.htm

11. Garcia LP, Freitas LRS, Höfelmann DA. Avaliação do impacto da Lei Maria da Penha sobre a mortalidade de mulheres por agressões no Brasil, 2001-2011. Epidemiol Serv Saude. 2013;22(3):383-94. doi: 10.5123/S1679-49742013000300003

12. Presidência da República (BR). Lei no.13.104, de 9 de março de 2015. Altera o art. 121 do Decreto-Lei no 2.848, de 7 de dezembro de 1940 Código Penal, para prever o feminicídio como circunstância qualificadora do crime de homicídio, e o art. 1 o da Lei no 8.072 , de 25 de julho de 1990, para incluir o feminicídio no rol dos crimes hediondos. Brasília: Diário Oficial da União, 2015.

13. Souza ER, Meira KC, Ribeiro AP. Homicides among women in the different Brazilian regions in the last 35 years: an analysis of age-periodbirth cohort effects. Cien Saude Colet. 2017;22(9):2949-62. doi: 10.1590/1413-81232017229.12392017

14. Meneghel SN, Hirakata VN. Femicídios: homicídios femininos no Brasil. Rev Saude Publica. 2011;45:564-74. doi: 10.1590/ S0034-89102011000300015

15. Martins-Filho PRS, Mendes MLT, Reinheimer DM. Femicide trends in Brazil: relationship between public interest and mortality rates. Arch Womens Ment Health. 2018;21(5):579-82. doi: 10.1007/s00737-018-0842-1

16. Meneghel SN, Rosa B, Ceccon RF, Hirakata VN, Danilevicz IM. Femicides: a study in Brazilian state capital cities and large municipalities. Cien Saude Colet. 2017;22(9):2963-70. doi: 10.1590/1413-81232017229.22732015

17. Instituto Brasileiro de Geografia e Estatística. Estatísticas do Registro Civil 2009[Internet]. 2010[cited 2018 Aug 28]. Available from: https:// www.ibge.gov.br/estatisticas/sociais/populacao/9110-estatisticas-do-registro-civil.html

18. Vyas $\mathrm{S}$, Jansen $\mathrm{H}$. Unequal power relations and partner violence against women in Tanzania: a cross-sectional analysis. BMC Womens Health 2018;18(1):185. doi: 10.1186/s12905-018-0675-0

19. Meneghel SN, Mueller B, Collaziol ME,Quadros MM. Repercussões da lei Maria da Penha no enfrentamento da violência de gênero. Cien Saude Colet. 2013;18(3):691-700. doi: 10.1590/s1413-81232013000300015

20. Memiah P, Ah Mu T, Prevot K. The prevalence of intimate partner violence, associated risk factors, and other moderating effects: findings from the Kenya National Health Demographic Survey. J Interpers Violence. 2018:886260518804177. doi: 10.1177/0886260518804177

21. Benebo FO, Schumann B, Vaezghasemi M. Intimate partner violence against women in Nigeria: a multilevel study investigating the effect of women's status and community norms. BMC Womens Health. 2018; 18(1): 136. doi: 10.1186/s12905-018-0628-7

22. Margarites AF, Meneghel SN, Ceccon RF. Feminicides in Porto Alegre: how many? who are they? Rev Bras Epidemiol. 2017;20(2):225-36. doi: 10.1590/1980-5497201700020004.

23. Prieto-Carrón M, Thomson M, Macdonald M. No more killings! women respond to femicides in Central America. Gender Developm [Internet]. 2007 [cited 2017 Aug 28];15(1):25-40. Available from: www.jstor.org/stable/20461179

24. Dobash RE, Dobash RP, Cavanagh K, Lewis R. Not an ordinary killer-Just an ordinary guy: when men murder an intimate woman partner. Violence Against Women. 2004;10(6):577-605. doi: https://doi.org/10.1177/1077801204265015

25. Organização Pan-Americana de Saúde. Violência contra a mulher. Estratégia e Plano de Ação para o reforço do sistema de saúde para abordar a violência contra a mulher[Internet]. 2015 [cited 2018 Nov 10]. Available from: http://iris.paho.org/xmlui/bitstream/ handle/123456789/18386/CD549Rev2_por.pdf?sequence=9\&isAllowed=y.

26. Lara R. Serial Killer de Goiânia é condenado a vinte anos de prisão. Veja [Internet]. Editora Abril, 16 Feb 2016[cited 2018 Nov 10]. Available from: https://veja.abril.com.br/brasil/serial-killer-de-goiania-e-condenado-a-20-anos-de-prisao/

27. Leites GT, Meneghel SN, Hirakata VN. Female homicide in Rio Grande do Sul, Brazil. Rev Bras Epidemiol [Internet]. 2014[cited 2017 Aug 28];17(3):642-53 Available from: http://www.scielo.br/pdf/rbepid/v17n3/1415-790X-rbepid-17-03-00642.pdf

28. Franca EB, Passos VMA, Malta DC. Cause-specific mortality for 249 causes in Brazil and states during 1990-2015: a systematic analysis for the global burden of disease study 2015. Popul Health Metr. 2017;15(1):39. doi: 10.1186/s12963-017-0156-y

29. Munévar DI. Delito de feminicidio. Muerte violenta de mujeres por razones de género. Estud Soc Jur [Internet]. 2012 [cited 2017 Aug 28];14(1):135-75 Available from: http://www.corteidh.or.cr/tablas/r28986.pdf 
30. Matos MA, Caetano KA, Franca DD, Pinheiro RS, Moraes LC, Teles SA. Vulnerability to sexually transmitted infections in women who sell sex on the route of prostitution and sex tourism in central Brazil. Rev Latino-Am Enfermagem. 2013;21(4):906-12. doi: 10.1590/ s0104-11692013000400011

31. Jovanovski N, Tyler M. "Bitch, You Got What You Deserved!": violation and violence in sex buyer reviews of legal brothels. Violence Against Women. 2018;24(16):1887-908. doi: 10.1177/1077801218757375

32. Farley M, Golding JM, Matthews ES, Malamuth NM, Jarrett L. Comparing sex buyers with men who do not buy sex: new data on prostitution and trafficking. J Interpers Violence. 2017;32(23):3601-25. doi: 10.1177/0886260515600874

33. Geneva Declaration on Armed Violence and Development. Global burden of armed violence 2015: every body counts. Periodical Global burden of armed violence 2015: every body counts [Internet]. 2015[cited 2019 Jan 28]. Available from: http://www.genevadeclaration.org/ measurability/global-burden-of-armed-violence/global-burden-of-armed-violence-2015.html

34. Naved RT, Mamun MA, Parvin K. Magnitude and correlates of intimate partner violence against female garment workers from selected factories in Bangladesh. PLoS One. 2018;13(11):e0204725. doi: 10.1371/journal.pone.0204725 